\title{
Hydroxylation of Alkanes and Fatty Acids in Saccharomycopsis lipolytica. Evidence for the Involvement of Cytochrome P-450
}

\author{
By REMY MARCHAL, ${ }^{1}$ MAURICE METCHE ${ }^{2}$ AND \\ JEAN-PAUL VANDECASTEELE ${ }^{1 *}$ \\ ${ }^{1}$ Direction Environnement et Biologie Pétrolière, Institut Français du Pétrole, 92506 \\ Rueil-Malmaison, France \\ ${ }^{2}$ Laboratoire de Biochimie Appliquée, Ecole Nationale Supérieure d'Agronomie et des \\ Industries Alimentaires, 54000 Nancy, France
}

(Received 7 April 1981; revised 17 August 1981)

\begin{abstract}
Growth of the yeast Saccharomycopsis lipolytica on $n$-alkanes induced a hydroxylation system which, in the presence of NADPH and $\mathrm{O}_{2}$, converted lauric acid into $\omega$-hydroxylauric acid. The specific hydroxylation activity was lower with the physiological substrate $n$-hexadecane than with lauric acid. This system was particulate and did not act on $N$ - and $O$-dealkylated compounds. It was strongly inhibited by $\mathrm{CO}$ and its enzymic activity was unstable. Because of the presence of cytochrome oxidase in the preparations, spectral demonstration of the presence of cytochrome P-450 was difficult but could be achieved with the techniques developed.
\end{abstract}

\section{INTRODUCTION}

The first step in the degradation of $n$-alkanes in yeasts and other micro-organisms is the hydroxylation of the terminal methyl group (Ratledge, 1978). In Candida tropicalis (Lebeault et al., 1971; Gallo et al., 1971) this reaction is catalysed by a monooxygenase which requires $\mathrm{O}_{2}$ and NADPH, NADH having an effect synergistic with that of NADPH. The hydroxylation system of $C$. tropicalis has been partially purified and resolved into three components: a cytochrome P-450, a cytochrome P-450 reductase and a thermostable lipid (Duppel et al., 1973). This, as well as the capacity to demethylate several drugs (Schunck et al., 1978a), suggests a marked similarity between the yeast and the mammalian liver microsomal system.

A microsomal system also involving cytochrome P-450 has been reported in Candida guilliermondii. This system converts $n$-hexadecane into $n$-hexadecanol and palmitic acid (Schunck et al., 1978b). As in the case of C. tropicalis, cytochrome P-450 is induced by growth on $n$-alkanes (Tittelbach et al., 1976).

Among alkane-utilizing yeasts, Saccharomycopsis lipolytica stands out as the organism which has been the most thoroughly studied at the biochemical and genetic levels. However, in this yeast, the nature of the system of initial degradation of $n$-alkanes has not been clearly established. According to Delaisse \& Nyns (1974), the hydroxylating system also consists of a cytochrome P-450. However, Peterson (1970) did not succeed in showing the presence of cytochrome P-450 in cell-free extracts of this yeast. Moreover, Rohde et al. (1975) briefly reported that oxidation of $n$-hexadecane by extracts of $S$. lipolytica required NADH but not NADPH.

This present work was undertaken in order to obtain a better understanding of the $n$-alkane hydroxylation system of $S$. lipolytica, and the properties of this system are described below. 


\section{METHODS}

Organisms and culture. Saccharomycopsis lipolytica 102 was grown in batch culture in a stirred fermenter as previously described (Marchal et al., 1977), except that $n$-hexadecane replaced the $n$-paraffin cut as the carbon source and $\mathrm{NH}_{4} \mathrm{OH}$ replaced $\mathrm{KOH}$ as the $\mathrm{pH}$-regulating agent. After $20 \mathrm{~h}$ of growth, the cells were harvested by centrifugation $\left(48000 \mathrm{~g}\right.$ for $10 \mathrm{~min}$ at $\left.4{ }^{\circ} \mathrm{C}\right)$. The yeast pellet was immediately washed with $50 \mathrm{~mm}$-potassium phosphate buffer ( $\mathrm{pH} \mathrm{7.0)}$ to remove residual $n$-hexadecane. Candida tropicalis CBS 6947 was grown and harvested in exactly the same manner.

Enzyme preparations. A suspension of $8 \mathrm{~g}$ (wet wt) organisms in $8 \mathrm{ml} 50 \mathrm{~mm}$-potassium phosphate buffer ( $\mathrm{pH} \mathrm{7.0)}$ was shaken with $16 \mathrm{~g}$ glass beads $(0.5 \mathrm{~mm}$ diam.) in a refrigerated ball mill (Braun MSK) for $1.5 \mathrm{~min}$. The broken organisms were centrifuged in two steps, first for $5 \mathrm{~min}$ at $1000 \mathrm{~g}$ and then for $15 \mathrm{~min}$ at $10000 \mathrm{~g}$ in order to prevent the smaller particles being carried along in the pellet. The supernatant, which constituted the crude extract, was centrifuged for $90 \mathrm{~min}$ at $100000 \mathrm{~g}$ in order to recover the particulate fraction. A suspension of this pellet in the same phosphate buffer could be kept frozen at $-80^{\circ} \mathrm{C}$ for several months without any significant loss of hydroxylation activity. The rat liver extract was a microsomal preparation obtained from rats induced by Aroclor 1254 (Ames et al., 1975).

Determination of the hydroxylation activity with hexadecane and laurate. The reaction was performed under air at $30^{\circ} \mathrm{C}$ in $25 \mathrm{ml}$ sealed glass vials which were agitated at $200 \mathrm{rev} . \mathrm{min}^{-1}$. The incubation time was 20 min (unless otherwise stated). The reaction mixture $(1 \mathrm{ml})$ had the following composition (unless otherwise stated): $50 \mu \mathrm{mol}$ potassium phosphate buffer ( $\mathrm{pH} 7.0$ ), $2.5 \mu \mathrm{mol}$ NADPH, $2.5 \mu \mathrm{mol}$ NADH, $20 \mu \mathrm{mol}$ sodium isocitrate, $38 \mu \mathrm{mol}$ glucose, NADP ${ }^{+}$-linked isocitrate dehydrogenase (EC 1.1.1.42) from pig heart $(20 \mathrm{U})$, glucose dehydrogenase (EC 1.1.1.47) from Bacillus subtilis $(1.5 \mathrm{U}), 124 \mathrm{nmol}\left[1-{ }^{14} \mathrm{C}\right.$ laurate or $n-\left[1-{ }^{14} \mathrm{C} \mid\right.$ hexadecane $(833 \mathrm{~Bq})$ dissolved in $350 \mu \mathrm{mol}$ ethanol, and cell-free extract (1-4 mg protein). In the case of laurate, which is water-soluble at the concentration used, the reaction was initiated by addition of the laurate solution in ethanol. In the case of hexadecane, which is practically insoluble in water, emulsification of the reaction mixture containing all components except NADPH was performed by sonication $\left(15 \mathrm{~s}\right.$ at $\left.0^{\circ} \mathrm{C}\right)$ before initiation of the reaction by addition of NADPH.

The reaction was stopped by the addition of $50 \mu \mathrm{l} 50 \%(\mathrm{v} / \mathrm{v}) \mathrm{H}_{2} \mathrm{SO}_{4}$. The acidified medium was agitated for 1 min with $4 \mathrm{ml}$ ether. The two phases were separated by centrifugation $(5 \mathrm{~min}$ at $10000 \mathrm{~g})$ and the organic phase was easily withdrawn after freezing the aqueous phase in a bath of acetone/solid $\mathrm{CO}_{2}$. After evaporation of the ether phase in a $5 \mathrm{ml}$ vial ('reacti-vial' from Pierce, Rockford, Ill., U.S.A.), the residue was taken up twice with two $0.1 \mathrm{ml}$ amounts of ether and applied to a thin-layer plate of silica gel. The plate was developed with ether/hexane/acetic acid $(60: 40: 1$, by vol.). The composition of this mixture had been selected for optimal separation between lauric acid and its oxidation products. The positions of the radioactive spots were detected by autoradiography (exposure time of $3 \mathrm{~d}$ at $4{ }^{\circ} \mathrm{C}$ ). The spots were scraped off and placed in vials containing $15 \mathrm{ml}$ of a scintillator solution $[4 \mathrm{~g}$ 2,5-diphenyloxazole and $0.5 \mathrm{~g} p$ - $(O$-methylstyryl)benzene per litre toluene $l$. The radioactivity of the residual substrate was used as an internal standard for the calculation of enzymic activity which included all products.

In preliminary experiments, we compared the separation obtained with silicic acid columns (Kusunose et al., 1964) and with thin-layer plates. The second method gave the best results. We have also compared the separation obtained on thin-layer plates with or without preliminary ether extraction. The direct application of the sample was retained only in the case of assays with $n$-hexadecane as the substrate in the presence of detergent, the extraction with ether being ineffective in this case.

Determination of the hydroxylation activity with $\mathrm{O}$ - and $\mathrm{N}$-alkylated compounds. Oxidations of $\mathrm{O}$ - and $\mathrm{N}$-alkylated compounds were performed as described by Duppel et al. (1973) with aminopyrine, anisole, dimethylnaphthylamine or methylamine as substrates, using the reagent described by Nash (1953) to measure the formaldehyde produced by the demethylation reaction. Demethylation of [dimethylamine ${ }^{14} \mathrm{Claminopyrine}$ was also estimated using the method of Poland \& Nebert (1972).

Dealkylation of ethoxycoumarin was measured by a modification of the fluorimetric method of Ullrich \& Weber (1972). The apparatus used was an Eppendorf photometer equipped with the fluorimetric kit 1030 (passing bands: 313-360 nm for primary filter and 470-3000 nm for secondary filter). In our assay, in order to minimize interference due to the fluorescence of NADPH and NADH, the initial concentration of these compounds was lowered to $16 \mu \mathrm{M}$ for NADPH and $10 \mu \mathrm{M}$ for NADH and the concentrations were kept constant during the course of the reaction by use of the reduced pyridine nucleotide-regenerating systems mentioned above. The minimum activity detectable was $5 \mathrm{pmol} \mathrm{min}^{-1}(\mathrm{mg} \text { protein })^{-1}$.

Spectrophotometric examination. Examinations of the CO-complexes of cytochromes were carried out on particulate fractions with a Beckman 25 spectrophotometer. The reduced minus reduced $+\mathrm{CO}$ difference spectra (Omura \& Sato, 1964) and the reduced + CO minus oxidized + CO spectra (Schoene et al., 1972) were investigated.

Protein determination. The protein content of the extracts was measured by the method of Lowry. 
Materials. $n-\left[1-{ }^{14} \mathrm{C}\right]$ Hexadecane, $\left[1-{ }^{14} \mathrm{C}\right]$ lauric acid and $\left[\right.$ dimethylamine $-{ }^{-14} \mathrm{C}$ laminopyrine were purchased from Amersham and $\left[1-{ }^{14} \mathrm{C}\right]$ myristic acid, $\left[1-{ }^{14} \mathrm{C}\right.$ palmitic acid and $\left[1-{ }^{14} \mathrm{C}\right]$ stearic acid from the Commissariat à l'Energie Atomique, Gif sur Yvette, France. $\omega$-Hydroxylauric acid was obtained from Aldrich Europe, Beerse, Belgium. Glucose dehydrogenase and NADP+-linked isocitrate dehydrogenase were from Boehringer. The thin-layer chromatography plates of silica gel $60(20 \times 20 \mathrm{~cm}$, layer thickness $0.25 \mathrm{~mm})$ were from Merck. Autoradiography was carried out using a Kodirex radiographic film (Kodak). $n-\left[1-{ }^{14} \mathrm{C}\right]$ Hexadecane, which was contaminated with about $1 \%$ of an impurity identified as $n$-hexadecanol, was purified by thin-layer chromatography before use.

\section{RES ULTS}

\section{Characterization of the hydroxylation system}

Cofactor requirements. Initial experiments were carried out with laurate as the substrate. Figure 1 shows an autoradiogram of the thin-layer chromatographic separation performed on the products formed in assays carried out under various conditions. Laurate was oxidized to $\omega$-hydroxylaurate under the conditions of assay 1 . In assay $5, \omega$-hydroxylaurate was again produced but a further oxidation to the dicarboxylic acid also occurred. Both products were identified by comparison of their $R_{F}$ values with those of the pure reference compounds. In addition, the formation of dodecanedioate confirmed that the initial hydroxylation of laurate took place on the terminal methyl group. The hydroxylation activities presented in the legend of Fig. 1 show that oxidation of laurate by a particulate extract of $S$. lipolytica requires the presence of both $\mathrm{O}_{2}$ and NADPH. A much lower, but nevertheless significant activity, was found when NADPH was replaced by NADH.

The synergistic effect of NADPH and NADH on hydroxylation activity, demonstrated in Table 1, suggests that the role of NADH was not merely to allow the functioning of an independent NADH-linked hydroxylation system. Table 1 also shows that the hydroxylation activity was increased in the presence of regenerating systems of NADH and NADPH; while Table 2 shows that this increase could be ascribed to the regeneration of NADH, but not of NADPH. This effect is probably related to the fact that, in crude extracts, the NADH oxidase activity $\left[28 \mathrm{nmol} \mathrm{min} \mathrm{m}^{-1}(\mathrm{mg} \text { protein })^{-1}\right]$ was appreciably higher than the corresponding NADPH oxidase activity $\left[5 \mathrm{nmol} \mathrm{min}{ }^{-1}(\mathrm{mg} \text { protein })^{-1}\right]$. The replacement of NADPH and $\mathrm{O}_{2}$ by hydrogen peroxide or by cumene hydroperoxide both at a concentration of $3.3 \mathrm{~mm}$ (Nordblom et al., 1976) was unsuccessful.

Substrate specificity. The specificity of the enzymic system is illustrated in Tables 3 and 4. All the fatty acids tested and, in particular, laurate were well utilized (Table 3). On the contrary, with the physiological substrate, $n$-hexadecane, the activity was surprisingly low (about $1 \%$ of the activity with laurate). The addition of Triton X-100 or cholate at $1 \mathrm{~g}^{-1}$ or Tween 80 at $1,5,10$ or $20 \mathrm{~g}^{-1}$ did not markedly improve the activity with this substrate. Control experiments (Table 4) were performed with rat liver microsomes, which are known to hydroxylate alkanes (Das et al., 1968), and with extracts of C. tropicalis CBS 6947; activities of the same order of magnitude were obtained. These results are clearly different from those of Lebeault et al. (1971), who reported a hydroxylation activity as high as $800 \mathrm{pmol} \mathrm{min}^{-1}$ (mg protein $)^{-1}$ in $C$. tropicalis LM 7 extracts but only four times more activity for laurate.

Methylamine, dimethylnaphthylamine and anisole were not dealkylated with significant production of formaldehyde measured as described in Methods.

General properties of the hydroxylation system. Phosphate buffer was the best of the various buffers tested (Table 5, expt 1) and the activity in this buffer was found to be maximum at $\mathrm{pH} 7.0$ (Table 5 , expt 2). With phosphate buffer, the velocity of the reaction with $124 \mu \mathrm{M}$-laurate and a crude extract $\left(2.5 \mathrm{mg}\right.$ protein $\left.\mathrm{ml}^{-1}\right)$ was approximately constant for 15 min and slowly declined up to $25 \mathrm{~min}$. The velocity of the reaction with $124 \mu \mathrm{M}$-laurate was also proportional to the amount of crude extract used up to $3.5 \mathrm{mg}$ protein $\mathrm{ml}^{-1}$. 


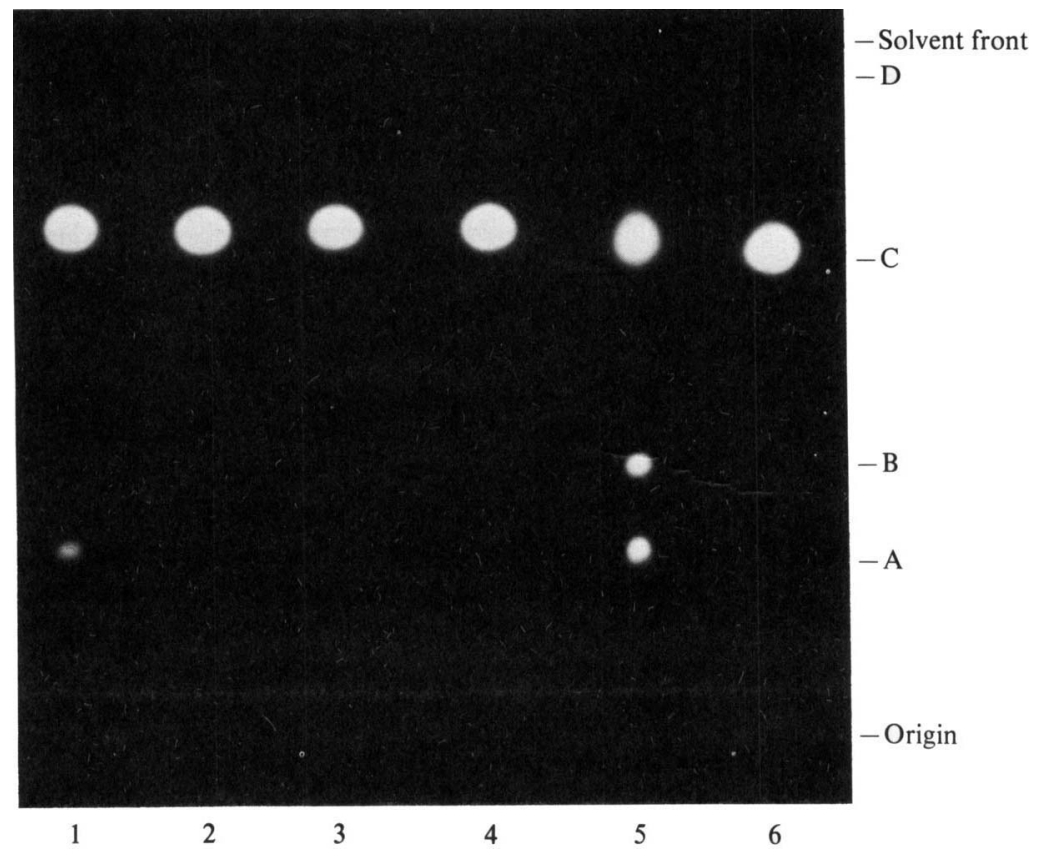

Fig. 1. Characterization of the hydroxylation activity for laurate and of its products in S. lipolytica cell-free preparations, by autoradiography of the chromatogram obtained for assays performed in the following conditions. Assay mixtures contained a particulate fraction $\left(1.33 \mathrm{mg}\right.$ protein $\mathrm{ml}^{-1}$, except in assay 5 which contained $6.65 \mathrm{mg}$ protein $\left.\mathrm{ml}^{-1}\right), 124 \mu \mathrm{M}$-laurate, $50 \mathrm{~mm}$-potassium phosphate $(\mathrm{pH} 7.5$ ) and the coenzymes indicated below, each used at a concentration of $2.5 \mathrm{~mm}$, but no reduced pyridine nucleotide regenerating systems. The incubation period was $15 \mathrm{~min}$ (except in assay 5, where it was $30 \mathrm{~min}$ ). The coenzymes used in each assay and the corresponding hydroxylation activities $1 \mathrm{pmol} \mathrm{min}^{-1}$ (mg protein) $)^{-1}$ ] obtained were: assay $1-\mathrm{NADPH}, 315 ; 2-\mathrm{NADH}, 50 ; 3-\mathrm{NAD}^{+}$and $\mathrm{NADP}^{+}, 10$; 4 - no coenzyme, 33;5 - NADPH and NADH, 193;6-NADPH, 38. All the assays were performed aerobically (except assay 6 which was incubated under $\mathrm{N}_{2}$ ). The particular conditions of assay 5 (large amount of extract, longer period of incubation) were chosen to maximize the formation of products for identification purposes; as a consequence, the enzymic activity measured in this assay was no longer linear versus time and protein concentration. Products: A, $\omega$-hydroxylaurate; B, dodecanedioate; C, laurate; $\mathrm{D}$, unidentified product.

\section{Table 1. Synergistic effects of NADPH and NADH in laurate hydroxylation}

A particulate fraction from $S$. lipolytica was used. The substrate was $124 \mu \mathrm{M}$-laurate, and assay mixtures contained the coenzymes indicated (each used a concentration of $2.5 \mathrm{~mm}$ ). Reduced pyridine nucleotide regenerating systems were added only where indicated.

$$
\text { Coenzyme(s) } \begin{gathered}
\text { Hydroxylation activity } \\
{\left[\mathrm{pmol} \mathrm{min} \mathrm{m}^{-1}(\mathrm{mg} \text { protein })^{-1}\right]}
\end{gathered}
$$

$\begin{array}{lc}\text { NADPH } & 332 \\ \text { NADH } & 120 \\ \text { NADPH + NADH } & 638 \\ \text { NADPH + NADH } & 1376^{*}\end{array}$

* NADPH and NADH regenerating systems added.

Table 6 shows that the hydroxylation activity was localized in the particulate fraction. The instability of the activity of the system (see below) probably explains the lower activity found in the reconstituted extract.

The hydroxylation system was induced by growth of the yeast on $n$-hexadecane, as in $C$. tropicalis (Gilewicz et al., 1979). The activity with laurate in particulate preparations from 
Table 2. Effect of the reduced pyridine nucleotide regenerating systems on the hydroxylation activity

A crude extract of $S$. lipolytica was used $\left(2.5 \mathrm{mg}\right.$ protein $\mathrm{ml}^{-1}$ in the assay mixture). The substrate was $124 \mu \mathrm{M}$-laurate, and assay mixtures contained the coenzymes (each used at a concentration $2.5 \mathrm{~mm}$ ) and reduced pyridine nucleotide generating systems indicated. The incubations were performed in $50 \mu \mathrm{M}$-potassium phosphate buffer ( $\mathrm{pH} 7 \cdot 5)$.

\begin{tabular}{llc}
\multicolumn{1}{c}{ Coenzyme(s) } & $\begin{array}{c}\text { Reduced pyridine } \\
\text { nucleotide } \\
\text { generating system(s) }\end{array}$ & $\begin{array}{c}\text { Hydroxylation activity } \\
\text { [pmol min }\end{array}$ \\
None & None & \\
NADP protein $)^{-1}$ ]
\end{tabular}

Table 3. Hydroxylation activities with fatty acid substrates

A crude extract from $S$. lipolytica was used. The initial concentration of each substrate was $124 \mu \mathrm{M}$.

$\begin{array}{lr}\text { Laurate }\left(\mathrm{C}_{12}\right) & 812 \\ \text { Myristate }\left(\mathrm{C}_{14}\right) & 116 \\ \text { Palmitate }\left(\mathrm{C}_{16}\right) & 81 \\ \text { Stearate }\left(\mathrm{C}_{18}\right) & 150\end{array}$

Table 4. Hydroxylation activities for n-hexadecane and laurate of $S$. lipolytica, $C$. tropicalis and rat liver

Crude extracts were used except in the case of $C$. tropicalis CBS 6947 where a particulate fraction was utilized. The substances were each at an initial concentration of $124 \mu \mathrm{M}$.

\begin{tabular}{|c|c|c|}
\hline Origin of extract & Substrate & $\begin{array}{c}\text { Hydroxylation activity } \\
{\left[\text { pmol } \min ^{-1}(\text { mg protein })^{-1}\right]}\end{array}$ \\
\hline S. lipolytica & $\begin{array}{l}n \text {-Hexadecane } \\
\text { (control, } 0 \text { min) } \\
n \text {-Hexadecane } \\
\text { Laurate }\end{array}$ & $\begin{array}{r}0.8 \\
\\
6 \cdot 7 \\
568\end{array}$ \\
\hline C. tropicalis & $\begin{array}{l}n \text {-Hexadecane } \\
\text { Laurate }\end{array}$ & $\begin{array}{l}8 \cdot 0 \\
1720\end{array}$ \\
\hline Rat liver & $\begin{array}{l}n \text {-Hexadecane } \\
\text { Laurate }\end{array}$ & $\begin{array}{l}3 \cdot 4 \\
155\end{array}$ \\
\hline
\end{tabular}

glucose-grown cultures [92 pmol $\left.\min ^{-1}(\mathrm{mg} \text { protein })^{-1}\right]$ was, in fact, several times lower than that of corresponding preparations obtained from cultures grown on $n$-hexadecane $[722 \mathrm{pmol}$ $\min ^{-1}$ (mg protein $)^{-1}$. Lebeault et al. (1971) also reported a residual activity in cultures of $C$. tropicalis grown on glucose.

Hydroxylation activity was sensitive to inhibition by $\mathrm{CO}$ : when air in the assay vial was replaced by $\mathrm{O}_{2} / \mathrm{CO}(4: 1, \mathrm{v} / \mathrm{v})$, the activity was reduced by $86 \%$ [from 301 to $43 \mathrm{pmol} \mathrm{min}^{-1}$ (mg protein) $)^{-1}$.

The stability of the hydroxylation system of $S$. lipolytica was found to be lower than that of C. tropicalis. Crude extracts stored at $4{ }^{\circ} \mathrm{C}$ lost $78 \%$ activity in $24 \mathrm{~h}$ in the case of $S$. lipolytica 102 and only $5 \%$ activity in the case of $C$. tropicalis CBS 6947 . The addition of $30 \%$ glycerol, $1 \mathrm{~mm}$-dithiothreitol, $1 \mathrm{~mm}$-EDTA or $4 \mathrm{~mm}$-phenylmethylsulphonyl fluoride or 
Table 5. Effect of the nature of the buffer and $\mathrm{pH}$ on the hydroxylation activity

Crude extracts were used. The substrate was $124 \mu \mathrm{M}$-laurate. The incubations were performed in 50 mM-buffer at the indicated pH. $\omega$-Hydroxylaurate represented $95-97 \%$ and dodecanedioate $3-5 \%$ of the products formed.

\begin{tabular}{|c|c|c|c|}
\hline $\begin{array}{l}\text { Expt } \\
\text { no. }\end{array}$ & Buffer* & $\mathrm{pH}$ & $\begin{array}{c}\text { Hydroxylation activity } \\
{\left[\mathrm{pmol} \mathrm{min}^{-1}(\mathrm{mg} \text { protein })^{-1}\right]}\end{array}$ \\
\hline \multirow[t]{6}{*}{1} & Potassium phosphate & $7 \cdot 0$ & 670 \\
\hline & Tris $/ \mathrm{HCl}$ & $7 \cdot 4$ & 240 \\
\hline & Imidazole & $7 \cdot 0$ & 40 \\
\hline & HEPES & $7 \cdot 0$ & 260 \\
\hline & MOPS & $7 \cdot 0$ & 160 \\
\hline & TES & $7 \cdot 0$ & 260 \\
\hline \multirow[t]{6}{*}{2} & Potassium phosphate & $6 \cdot 4$ & 550 \\
\hline & Potassium phosphate & 6.8 & 840 \\
\hline & Potassium phosphate & $7 \cdot 0$ & 920 \\
\hline & Potassium phosphate & $7 \cdot 2$ & 840 \\
\hline & Potassium phosphate & $7 \cdot 4$ & 540 \\
\hline & Potassium phosphate & $7 \cdot 7$ & 370 \\
\hline
\end{tabular}

* HEPES, $N$-2-hydroxyethylpiperazine- $N^{\prime}$-2-ethanesulphonate; MOPS, 3-( $N$-morpholino)propanesulphonate; TES, $N$-tris(hydroxymethyl)methyl-2-aminoethanesulphonate.

Table 6. Localization of hydroxylation activity in S. lipolytica

The substrate was $124 \mu \mathrm{M}$-laurate. The particulate fraction was obtained by ultracentrifugation of the crude extract as described in Methods. After resuspension in $50 \mathrm{~mm}$-potassium phosphate buffer ( $\mathrm{pH} 7 \cdot 0$ ), it was recentrifuged once for washing.

\begin{tabular}{|c|c|}
\hline Incubation condition & $\begin{array}{c}\text { Hydroxylation activity } \\
{\left[\mathrm{pmol} \mathrm{min}^{-1}(\mathrm{mg} \text { protein })^{-1}\right]}\end{array}$ \\
\hline $\begin{array}{l}\text { Control (crude extract, } 0 \mathrm{~min} \\
\text { incubation) }\end{array}$ & 1 \\
\hline Crude extract & 357 \\
\hline Particulate fraction & 435 \\
\hline Soluble fraction & 17 \\
\hline $\begin{array}{l}\text { Reconstituted crude extract } \\
\text { (soluble plus particulate fractions) }\end{array}$ & 161 \\
\hline
\end{tabular}

storage under $\mathrm{N}_{2}$ did not improve the stability of the $S$. lipolytica system. The activity in the presence of glycerol, however, was about twice that measured in its absence.

Spectral examination. In order to detect the presence of cytochrome P-450, particulate preparations of $S$. lipolytica incubated with $\mathrm{CO}$ were examined under the conditions of Omura \& Sato (1964). For comparison, similar experiments were carried out with $C$. tropicalis CBS 6947 and rat liver microsomal preparations. The spectra obtained (Fig. 2) clearly show in the microsomes of rat liver (spectrum $1 a$ ) and in $C$. tropicalis (spectrum $1 b$ ) the presence of the characteristic peak at $450 \mathrm{~nm}$ of cytochrome P-450. In the case of $S$. lipolytica (spectrum 1c), there was no evidence for the presence of this cytochrome in the particulate fraction. The spectrum presented a peak at about $427 \mathrm{~nm}$ and a trough at $443 \mathrm{~nm}$, which completely masked any cytochrome P-450 present in the preparation. In fact, the characteristics of this spectrum indicated the presence in our preparation of cytochrome $c$ oxidase (Okunuki, 1966). The trough at $443 \mathrm{~nm}$ resulted from the absorption of the Soret band of the reduced form of cytochrome oxidase. The procedure used by Schoene et al. (1972) to circumvent the interference of haemoglobin could be used here, since the Soret absorption peaks of the reduced $+\mathrm{CO}$ and oxidized forms of cytochrome oxidase both occur 

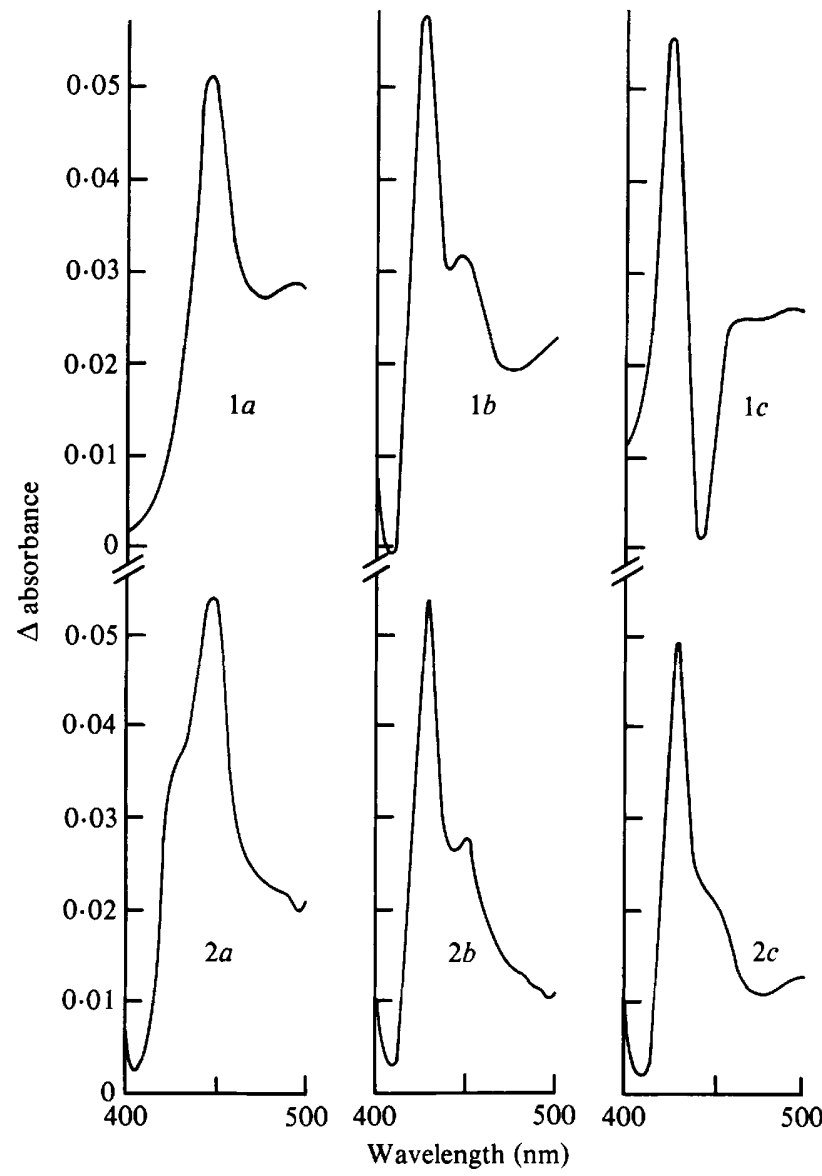

Fig. 2. Spectral detection of cytochrome P-450 in particulate preparations. (1) Differential spectra according to Omura \& Sato (1964) (reduced + CO minus reduced) and (2) differential spectra according to Schoene et al. (1972) (reduced + CO minus non-reduced $+\mathrm{CO}$ ): $(a)$ rat liver; $(b) C$. tropicalis CBS 6947; (c) S. lipolytica.

The shoulder at $426 \mathrm{~nm}$ in spectrum $2 a$ can be attributed to the presence of cytochrome $b_{5}$ in the rat liver preparation (Estabrook \& Werringloer, 1978) which may also contribute to spectra $2 b$ and $2 c$. Spectra quite similar to spectra $1 b$ and $2 b$ have been observed for another alkane-grown strain, $C$. tropicalis I.F.P. 10.

in the range $420-430 \mathrm{~nm}$ (Vanneste, 1966). The spectra obtained with this procedure indicated the presence of cytochrome P-450 in S. lipolytica extracts (spectrum $2 c$ ). However, the concentration was lower than in the preparations of rat liver (spectrum $2 a$ ) and $C$. tropicalis (spectrum $2 b$ ).

\section{DIS CUS SION}

The results presented here clearly establish that, as in C. tropicalis (Lebeault et al., 1971; Gallo et al., 1971; Duppel et al., 1973), the first step in the degradation of $n$-alkanes in $S$. lipolytica involves a monooxygenase system which requires $\mathrm{O}_{2}$ and NADPH, NADH having an effect synergistic with that of NADPH. As usually observed for hydroxylating systems from alkane-grown yeasts, this enzymic activity was induced by growth on $n$-alkanes but significant activity was present in glucose-grown organisms. Like most other comparable systems from eukaryotic micro-organisms, including the $C$. tropicalis system as described by 
Gallo et al. (1976) but not by Lebeault et al. (1971), the hydroxylase was localized in the particulate fraction. Because of its very low solubility in water, the physiological substrate, $n$-hexadecane, was not rapidly hydroxylated. Although this point has not been stressed by other authors, it probably has some generality as we have also observed it with $C$. tropicalis (Table 4) and Pseudomonas aeruginosa (Blanchet \& Vandecasteele, unpublished work). As addition of various detergents did not appreciably increase the rate of hexadecane hydroxylation, the question of the manner by which this reaction occurs inside the cell remains unanswered. More soluble compounds such as fatty acids, however, in particular lauric acid, were rapidly transformed into the corresponding $\omega$-hydroxyacids. $\mathrm{CO}$ strongly inhibited our hydroxylation system. The $S$. lipolytica system presents many similarities with that described for Torulopsis magnoliae (Heinz et al., 1970) which may contain cytochrome P-450 (Wiseman, 1977). In S. lipolytica, differential spectrophotometric spectra obtained using the method of Schoene et al. (1972) showed the presence of cytochrome P-450. The stability of the system, however, was quite poor and could not be improved by the addition of glycerol or dithiothreitol and EDTA. Because of the presence of cytochrome oxidase which interfered with the spectral measurements, it was not possible to determine from these measurements if the instability of the $S$. lipolytica hydroxylation system was due to denaturation of cytochrome P-450 to P-420, but it is possible that P-420 contributes to spectrum $1 c$ of Fig. 2. Instability prevented the purification required for further characterization of the hydroxylation system, such as recently described in the cases of $C$. tropicalis (Bertrand et al., 1979a,b) and Saccharomyces cerevisiae (Yoshida et al., 1977). An important difference between our system and that of $C$. tropicalis described by Duppel et al. (1973) was that our preparations did not dealkylate $N$ - and $O$-alkylated compounds. In fact, the narrow specificity displayed by $S$. lipolytica cytochrome P-450 is well in accord with its physiological role of oxidizing the long-chain alkanes used as carbon sources, just as the wide specificity of the homologous enzymes of mammalian liver reflects their involvement in the detoxification of a large spectrum of xenobiotic compounds.

In hydroxylation systems involving cytochrome P-450, an NADPH-cytochrome $c$ reductase can often be characterized as an individual enzyme after solubilization of the system, as recently illustrated in the case of $C$. tropicalis (Bertrand et al., 1979a, b) and Saccharomyces cerevisiae (Aoyama et al., 1978). Such an activity could not be characterized here because of the presence of an endogenous cytochrome $c$ reductase activity in our preparations.

Some of the enzymes allowing further metabolism of alcohols resulting from the action of the hydroxylating system studied have been detected in our preparations. As in $C$. tropicalis (Lebeault et al., 1970), an $\mathrm{NAD}^{+}$-dependent alcohol dehydrogenase activity was observed in $S$. lipolytica but it was found only in the soluble fraction of the extract. This activity measured

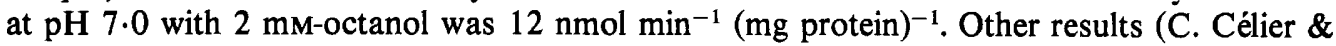
J. P. Vandecasteele, unpublished observations) indicated this activity was about 2.5 times higher in alkane-grown cells than in glucose-grown cells. The pyridine nucleotide-independent alcohol dehydrogenase which has been shown to be specific for alkane oxidation in Gram-negative bacteria (Tassin et al., 1973; Tauchert et al., 1975; Benson \& Shapiro, 1976) could not be detected in our preparations. $\mathrm{NAD}^{+}$-dependent aldehyde dehydrogenase activity [specific activity at $\mathrm{pH} 7.0$ with $2 \mathrm{mM}^{-o c t a n o l ~ w a s ~} 10 \mathrm{nmol} \mathrm{min}-1$ (mg protein) ${ }^{-1}$, in crude extracts] was also detected both in the soluble and the particulate fractions of $S$. lipolytica extracts. These activities probably explain the formation of dodecanedioate from $\omega$ hydroxylaurate in our preparations and their postulated role is the oxidation of primary alcohols to fatty acids in alkane degradation.

We thank Drs P. M. Dansette and Ph. Beaune for helpful discussions on spectral determination methods. 


\section{REFERENCES}

Ames, B. N., McCanN, J. \& Yamasaki, E. (1975). Methods for detecting carcinogens and mutagens with the Salmonella/mammalian microsome mutagenicity test. Mutation Research 31, 347-364.

aoyama, Y., Yoshida, Y., Kubota, S., Kumaoka, H. \& FurumichI, A. (1978). NADPH-cytochrome P-450 reductase of yeast microsomes. Archives of Biochemistry and Biophysics 185, 362-369.

Benson, S. \& Shapiro, J. (1976). Plasmid-determined alcohol dehydrogenase activity in alkane-utilizing strains of Pseudomonas putida. Journal of Bacteriology 126, 794-798.

Bertrand, J. C., Bazin, H., ZACEK, M., Gilewicz, M. \& Azoulay, E. (1979a). NADPH-cytochrome $c$ reductase of Candida tropicalis grown on alkane. European Journal of Biochemistry 93, 237-243.

Bertrand, J. C., Gilewicz, M., Bazin, H., ZaCeK, M. \& Azoulay, E. $(1979 b)$. Partial purification of cytochrome P-450 of Candida tropicalis and reconstitution of hydroxylase activity. FEBS Letters 105 , 143-146.

Das, M. L., Orrenius, S. \& ERnster, L. (1968). Fatty acid and hydrocarbon hydroxylation in rat liver microsomes. European Journal of Biochemistry 4, 519-523.

Delaissé, J. M. \& NyNS, E. S. (1974). Detection of cytochrome $\mathrm{P}-450$ in subcellular fractions of Endomycopsis lipolytica grown on $n$-hexadecane. Archives internationales de physiologie et de biochimie 82, 179.

Duppel, W., Lebeault, J. M. \& Coon, J. M. (1973). Properties of a yeast cytochrome P-450-containing enzyme system which catalyses the hydroxylation of fatty acids, alkanes and drugs. European Journal of Biochemistry 36, 583-592.

EstabroOK, R. W. \& WerRINGLOER, J. (1978). The measurement of difference spectra: application to the cytochromes of microsomes. Methods in Enzymology 52, 212-220.

Gallo, M., Bertrand, J. C. \& Azoulay, E. (1971). Participation du cytochrome P-450 dans l'oxydation des alcanes chez Candida tropicalis. FEBS Letters 19, 45-49.

Gallo, M., Roche, M. \& Azoulay, E. (1976). Microsomal cytochromes of Candida tropicalis grown on alkanes. Biochimica et biophysica acta 419, 425-434.

Gilewicz, M., ZACEK, M., Bertrand, J. C. \& Azoulay, E. (1979). Hydroxylase regulation in Candida tropicalis grown on alkanes. Canadian Journal of Microbiology 25, 201-206.

Heinz, E., Tulloch, A. P. \& Spencer, J. F. T. (1970). Hydroxylation of oleic acid by cell-free extracts of a species of Torulopsis. Biochimica et biophysica acta 202, 49-55.

Kusunose, M., Kusunose, E. \& Coon, M. J. (1964). Enzymatic $\omega$-oxidation of fatty acids. I. Products of octanoate, decanoate and laurate oxidation. Journal of Biological Chemistry 239, 1374-1380.

Lebeault, J. M., Meyer, E., Roche, B. \& Azoulay, E. (1970). Oxidation of higher alcohols in Candida tropicalis, cultivated on hydrocarbons. Biochimica et biophysica acta 220, 386-395.

Lebeault, J. M., Lode, E. T. \& Coon, M. J. (1971).
Fatty acid and hydrocarbon hydroxylation in yeast: role of cytochrome $\mathrm{P}-450$ in Candida tropicalis. Biochemical and Biophysical Research Communications 42, 413-419.

Marchal, R, Chaudé, O. \& Metche, M. (1977). Production of citric acid from $n$-paraffins by Saccharomycopsis lipolytica: kinetics and balance of the fermentation. European Journal of Applied Microbiology 4, 111-123.

NASH, T. (1953). Colorimetric estimation of formaldehyde by means of the Hantzsch reaction. Biochemical Journal 55, 416-421.

Nordblom, G. D., White, R. E. \& Coon, M. J. (1976). Studies of hydroperoxide-dependent substrate hydroxylation by purified liver microsomal cytochrome P-450. Archives of Biochemistry and Biophysics 175, 524-533.

OKUNUKI, K. (1966). Cytochrome and cytochrome oxidase. In Comprehensive Biochemistry, vol. 14: Biological Oxidations, pp. 235-308. Edited by M. Florkin \& E. H. Stotz. Amsterdam: Elsevier.

OMURA, T. \& SATo, R. (1964). Carbon monoxidebinding pigment of liver microsomes. I. Evidence for its hemaprotein nature. Journal of Biological Chemistry 239, 2370-2378.

Peterson, J. A. (1970). Cytochrome content of two pseudomonads containing mixed-function oxidase systems. Journal of Bacteriology 103, 714-721.

Poland, A. P. \& Nebert, D. W. (1972). Sensitive radiometric assay of aminopyrine $N$-demethylation. Journal of Pharmacology and Experimental Therapeutics 184, 269-277.

RATLEDGe, C. (1978). Degradation of aliphatic hydrocarbons. In Developments in Biodegradation of Hydrocarbons, vol. 1, pp. 1-46. Edited by A. Wiseman. London: Applied Science Publishers Ltd.

Rohde, H. G., Schröder, S., Schirpke, B. \& Weide, H. (1975). Abbau von $n$-Hexadecan- $1-{ }^{14} \mathrm{C}$ durch subzelluläre Partikeln aus Candida tropicalis. Zeitschrift für allgemeine Mikrobiologie 15, 195-201.

Schoene, B., FleischmanN, R. A., Remmer, H. \& Von Oldershausen, H. F. (1972). Determination of drug metabolizing enzymes in needle biopsies of human liver. European Journal of Clinical Pharmacology 4, 65-73.

Schunck, W. H., Riege, P. \& Kuhl, R. (1978a). Cytochrome P-450 of eukaryotic microorganisms. Pharmazie 33, H7, 412-414.

Schunck, W. H., Riege, P., Blasing, R., Honeck, H. \& Müllek, H. R. (1978b). Cytochrome P-450 and alkane hydroxylase activity in Candida guilliermondii. Acta biologica et medica germanica 37, K3-K 7.

Tassin, J. P., Celier, C. \& Vandecasteele, J. P. (1973). Purification and properties of a membranebound alcohol dehydrogenase involved in oxidation of long-chain hydrocarbons by Pseudomonas aeruginosa. Biochimica et biophysica acta 315, 220-232.

Tauchert, H., Roy, M., Schöpp, W. \& Aurich, H. (1975). Pyridine nucleotide-independent oxidation of long-chain aliphatic alcohols by an enzyme from Acinetobacter calcoaceticus. Zeitschrift für allgemeine Mikrobiologie 15, 457-460. 
Tittelbach, M., Rohde, H. G. \& Weide, H. (1976). Nachweis eines CO-bindenden Hämoproteins in Candida guilliermondii, Stamm $\mathrm{H} 17$, nach Kultur auf $n$-Alkanen. Zeitschrift für allgemeine Mikrobiologie 16, 155-156.

UlLRICH, V. \& WEBER, P. (1972). O-Dealkylation of 7-ethoxycoumarin by liver microsomes. Direct fluorimetric test. Hoppe-Seyler's Zeitschrift für physiologische Chemie 353, 1171-1177.

VANNESTE, W. H. (1966). The stoichiometry and absorption spectra of components $a$ and $a_{3}$ in cytochrome $c$ oxidase. Biochemistry 5, 838-848.
Wiseman, A. (1977). Microbial cytochromes P-450: drug applications. In Topics in Enzyme and Fermentation Biotechnology, vol. 1, pp. 172-184. Edited by A. Wiseman. Chichester: Ellis Horwood.

Yoshida, Y., Aoyama, Y., Kumaona, H. \& Kubota, S. (1977). A highly purified preparation of cytochrome P-450 from microsomes of anaerobically grown yeast. Biochemical and Biophysical Research Communications 78, 1005-1010. 